\title{
New Bio-Active Energy (BAE) Electrode for Radio Surgery Substantially Reduces Lateral Tissue Damage Compared to Classical Radio Electrodes
}

\author{
Novak Vukoje ${ }^{1}$, Nedad Solaji $\pitchfork^{2}$, Jon Garito ${ }^{3 *}$ and Milica Kovatevic $\$^{3}$ \\ ${ }^{1}$ Otorhinolaryngology, Petrovaradin, Serbia \\ ${ }^{2}$ Department of Pathology, University of Novi Sad, Faculty of Medicine, Serbia
}

${ }^{3}$ The innovator of new Bio-Active Energy (BAE) Electrode electrodes, USA

Submission: March 29, 2019; Published: April 15, 2019

*Corresponding author: Jon Garito, The innovator of new BAERF electrodes, USA

\begin{abstract}
Introduction: Radio Wave surgery is an atraumatic method used for both the cutting and coagulation of soft tissues. The cutting and coagulation are achieved through the use of a thin metal wire called a "surgical electrode,' which transmits and conveys radio wave energy in such a way as to heat the tissue. Through the newest innovation of Dr. Jon Garito, a new bio-active energy (BAE) electrode contains significant improvements over classical steel and tungsten radio frequency electrodes. A pathohistological analysis of skin lesions removed and Sampled samples for biopsy has shown that BAE electrodes lead to significantly lower lateral thermal damage to the cells in the tissue, thus not disturbing the quality of the obtained histological results. The aim of this research was to demonstrate the validity of pathohistological results in various pathological outgrowths of skin removed by radio wave 4 . Mhz surgery by analyzing them from the aspect of lateral tissue damage.
\end{abstract}

Materials \& Method: In 2018, Dr. Novak Vukoje removed 26 benign growths from the skin on the face and neck that were clinically identified as warts (14), fibromas (12) and moles (4). For the removal of 16 of the growths, the BAE Electrode was used. In the removal of the remaining 10 growths, a classical radio electrode was used.

Results: Pathohistological analysis has shown that the lateral tissue injury caused by the BAE Electrode ranges from only 5-8 microns, while the classical electrode has a much higher range from 20 to 90 microns.

Conclusion: The results indicate that the accumulation of lateral heat in the tissue using the appropriate BAE electrode is significantly lower than in the standard radio surgical electrode. This technology enables surgeons to perform atraumatic radio section / electro section with minimal lateral tissue damage, which is a significant advantage over classical electrodes and does not affect the ability to study pathohistological results.

\section{Introduction}

Most medical professionals specializing in plastic, aesthetic, and cosmetic surgery believe that the development of new and improved methodologies and technologies will drastically shape the future of these fields. Both conventional electro-surgical apparatuses and even surgical lasers can cause delayed wound healing and scarring due to excellerated thermal damage, and there is a constant desire for innovative designs that optimize healing and surgical outcomes for the patient. The Ellman Surgical 4.0 Dual which operates at 4 megahertz is able to preserve the pathological tissue by using a high frequency and low temperature. The use of this relatively new technology is rapidly increasing, because it achieves far superior results compared to any other existing surgical technique [1-8]. The BAE Electrode invented by Dr. Jon Garito enables us to brush, plane or layer away the pathological tissue with minimal thermal effect. The degree of lateral carbonization, the presence of necrotic tissue, and lateral tissue injury are all remarkably reduced, which is very significant for the pathohistological analysis. What makes this BAE Electrode unique, is that there is no heating of the electrode during the unit operation. This technology allows the Surgeon to deliver heat energy to the desired tissue while the electrode remains cold.

Our experience suggests that the application of these BAE Electrodes in a number of aesthetic procedures is superior to classic electrodes. The subtlety and precision are especially pronounced during surgical actions involving the use of excision, incision, shaving, etc. Their use in addition to precise cutting and coagulation reduces the lateral damage of the tissue, which in turn means faster healing of the wound, less smoke plume generation, reduced swelling, and lower likelihood of carbonization or destruction of the edge of the tissue. This leaves the tissue in a condition for adequate histological analysis. In addition, during the surgical procedure there is no adhesion of the tissue to the active part of the electrode, which accelerates the surgical 


\section{Global Journal of Otolaryngology}

procedure. The electrode is self-sterilized during use. The aim of this study was to evaluate what advantages, if any, the BAE Electrode holds over classical electrodes in the areas of lateral damage to the removed tumor, the degree of carbonization, and the effect on the tissue for later pathohistological analysis.

\section{Material \& Methods}

This study was done on the use of the new Bio-Active Energy (BAE) Electrode invented by Dr. Jon Garito in conjunction with the application of the Ellman Surgitron Dual Frequency RF 4.0 device. During the 2018 calendar year, Dr. Vukoje of Serbia removed 26 benign face and: neck lesions under local anesthesia. Of these 26 benign lesions that were removed from the face \& neck of patients, in 16 the BAE Electrode was used, and in 10, classic electrodes were used. The lesions were categorized as 14 clinical warts, \& 4 moles. There were more females to males in the study, represented by a 1.5:1.0 ration in subjects and averaging 19.4 years in age. The volume of the area of skin removed, in relation to skin union, ranged from 7 to $9 \mathrm{~mm}$. All lesions were removed by the same doctor, Dr. Vukoje, in the same location, at the ENT Clinic in Petrovaradin, Serbia, using local anesthesia. In order to analyze the samples, all 26 were fixed in a $10 \%$ formalin solution for 24 hours, dehydrated, and molded into paraffin according to the standard histological treatment procedure. Histological cuts of 5 microns thick were painted with hematoxylin and eosin for microscopic analysis, which involved the diagnosis of the pathological process, the completeness of excision, and the extent of thermal tissue damage on the edges of the preparation. The extent of thermal damage is defined as the width of the acellular and homogenized tissue at the edge of the preparation, as measured by the software.

\section{Results}

The authors Dr. Vukoje and Dr. Solajic, and Kovacevic compared the pathohistological results and the degree to which the tissue could be used for post-surgical analysis between those lesions removed using the BAE Electrode vs classical electrodes. The analysis of the histological compositions confirmed that all lesions were benign skin tags, fibromas, and moles. In each of the lesions analyzed, the full lesion was-able to-be removed regardless of which-electrode was. used. In the samples obtained with standard electrodes, the thickness of the thermally damaged edge was at least 20 and not more than 90 microns (Figure 5), whereas the thickness of the heat- damaged edge was only 5 to 8 microns using the BAE Electrode. As there is minimal damage to the surrounding tissue of the patient. Additionally, the lesser degree of thermal damage to the excised lesion allows for a better histopathological evaluation of the removed tissue. The width of the thermally damaged edge using the BAE Electrode is no greater than the diameter of the erythrocyte. Using the BAE Electrode could help alleviate the problem that many new surgeons face, which is how to best avoid causing large lateral tissue damage when using radio frequency surgical devices [912] (Figures 1-5).

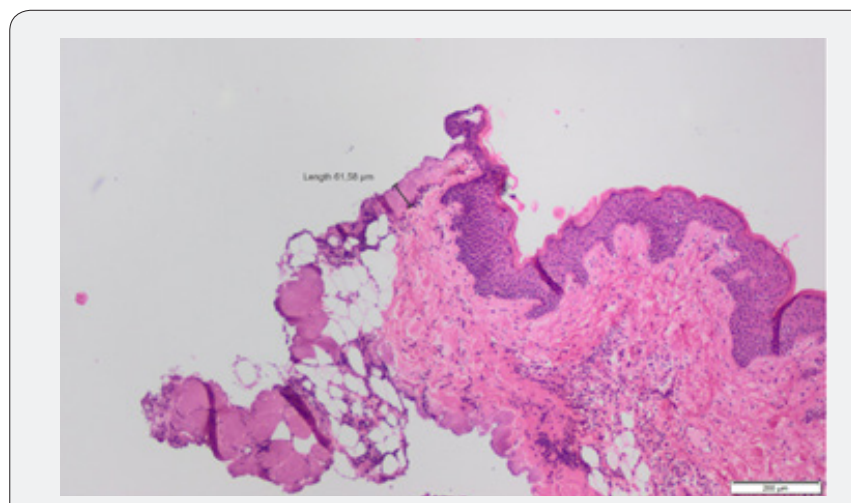

Figure 1: Skin tag (acrochordon) on the neck.
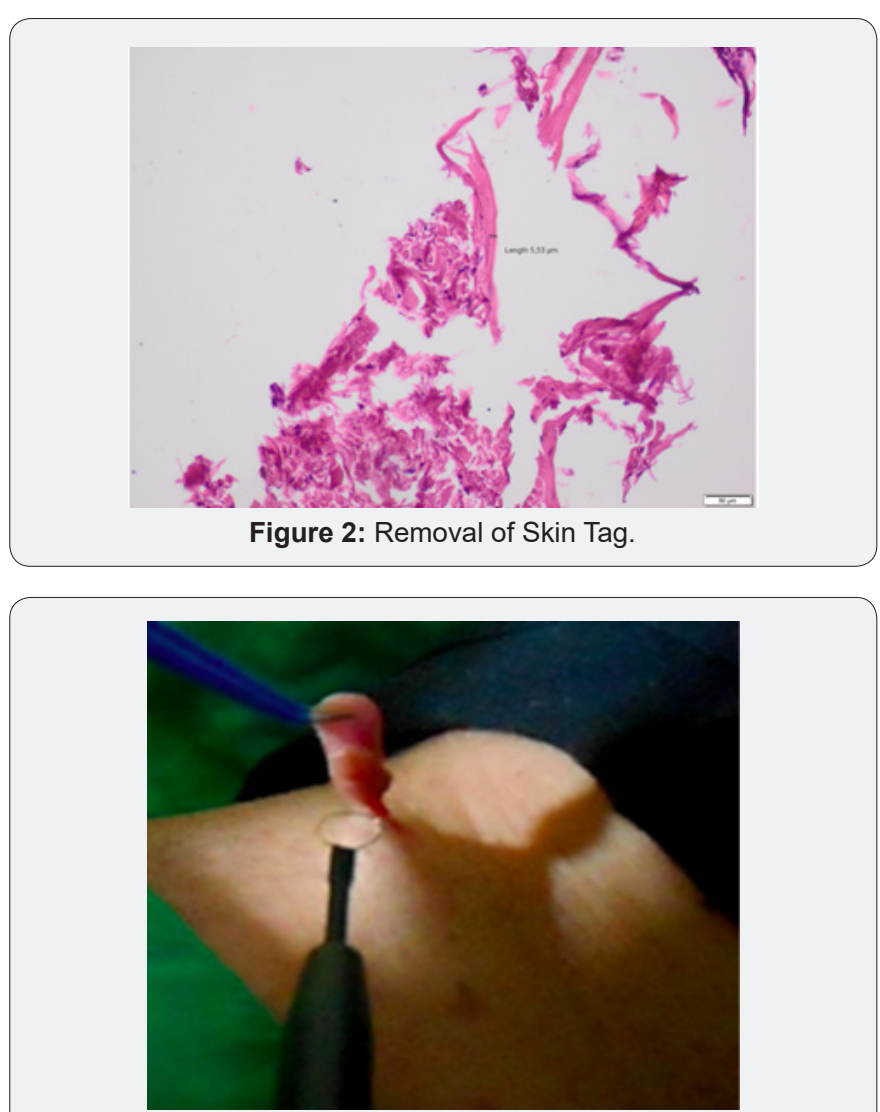

Figure 3: Removal of Skin Tag.

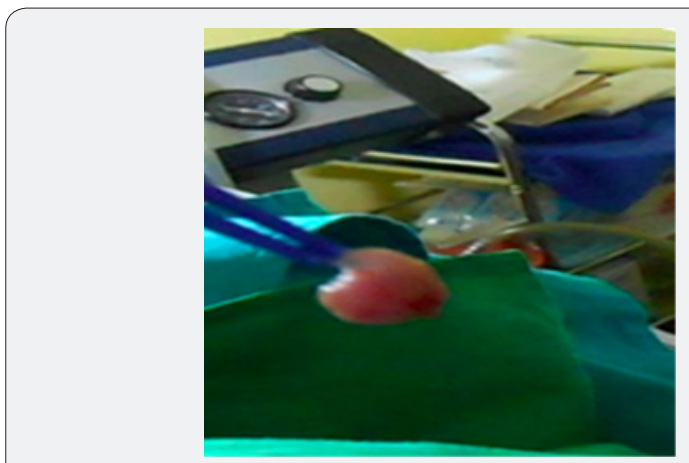

Figure 4: Removed Skin Tag. 


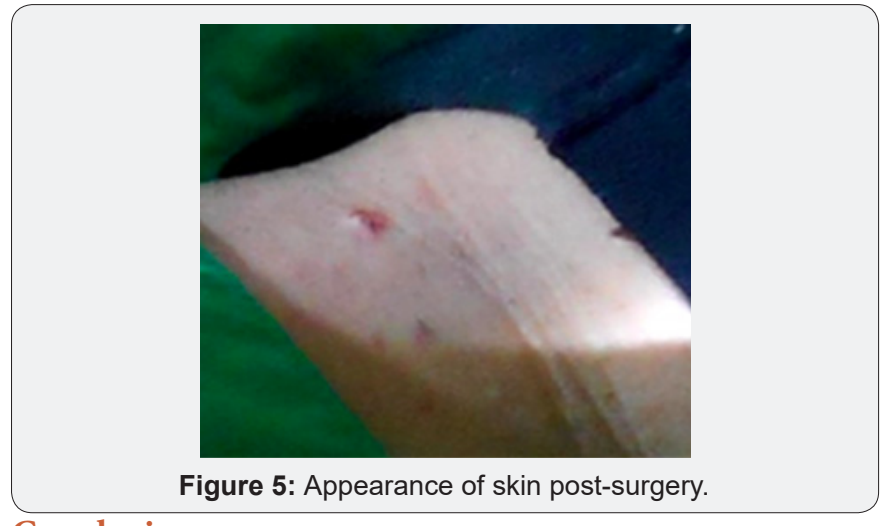

Conclusion

Using the BAE Electrode instead of a classical electrode is less traumatic and causes minimal destruction of the surrounding tissue, which is ideal for preserving the integrity of the tissue for further pathohistological analysis under a microscope [13-16]. In fact, as shown in Figures 5, an analysis of the edge of the skin lesions removed shows a much lower degree of iatrogenic tissue destruction as compared with classical electrodes. The minimal lateral tissue damage of only 5-8 microns that is possible using the BAE Electrode is unachievable with any other surgical device, including a laser, which destroys the tissue to a depth of several hundred micrometers. On the other hand, tissue samples taken for pathohistological analysts using BAE electrodes remain undamaged colors are unchanged, and there are no significant traces of the remainder of the necrotic tissue, Furthermore, scarring of the tissue using BAE Electrodes is minimal, and the cosmetic result is far superior for the patient. This aesthetic improvement in the appearance of the wound and the increased speed of healing are clear advantages of the BAE electrodes over classical electrodes, and they currently represent the best available option on the market for the removal of various lesions from the skin using radio frequency surgery.

\section{References}

1. Novak Vukoje and Jon Garito (2018) New solutions in Radio Wave Surgery-BAE electrodes Glob J Otolaryngol 18(2).

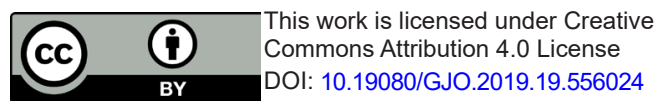

2. Novak Vukoje and Jon Garito (2017) Radio-Frequency Wave Application in Esthetic Surgery of ear and Neck Glob J Otolaryngol 8(4).

3. Novak Vukoje, Jon Garito and Milica Kovaéeviథ (2018) Otoplasty in childhood, Glob J Otolaryngol 18(4).

4. Fariba J, Nilforoushzadeh MA, Zarkoob H (2013) Patient satisfaction and efficacy of accent radiofrequency for facial skin. J Res Med 18(11): 970-975.

5. Rees TD, Lee YC, Coburn RJ (1973) Expanding hematoma after rhytidectomy: A Retrospective Study. Plast Reconstr Surg 51(2): 149-153.

6. Bridenstine JB (1998) Use of ultra-high frequency electrosurgery radio surgery for cosmetic surgical procedures. Dermatol Surge 24(3): 397-400.

7. Welch DB, Bruar P (2002) Two year follow wp: radiosurgery better than laser, Ocular Surgery News 20(12).

8. Oliver AC, Forouhar FA, Gillies CA, Servanski DR (1999) Transmission electron microscopy: Evaluation of damage in human oviducts caused by different surgical instruments. Ann Clin Lab Sci 29(4): 281-285.

9. Greenbaunt SS, Krul EA, Wattick K (1988) Comparison of $\mathrm{CO}_{2}$ laser and electrosurgery in the treatment of rhinophyma, J Amt Acad Dermatol 18(2): 363-368.

10. Saidi MH, Alright BD, Setzler FD, Sadler RX, Farlytr SA (1993) Diagnostic and therapeutic conization using loop radio thermal cautery 38(10): 775-779.

11. Saidi MH, Alright BD, Setzler FD, Sadler RX, Farlytr SA (1994) Comparison of office loop electrosurgical conization and cold knife conization. American Association of Gynecologic Laparoscopists 1(2): 135-139.

12. Turner RF, Cohen RA, Viet RL, Stephans SR, Weinstein SA (1992) Analysis of tissue margins of cone biopsy specimens obtained with "cold knife", $\mathrm{CO}_{2}$ and Nd: YAG lasers and a radio frequency surgical unit. The Journal of Reproductive Medicine 37(7): 607-610.

13. Mitchell JP, Lumb GN (1962) Principals of surgical diathermy and its limitations. Br j Surg 50(221): 314-320.

14. D' Arsonval A (1801) Action physiologique des courants alternatives. Sec Bio 43: 283-286.

15. D’ Arsonval A (1893) Action physiologique des courants alternatives a grand frequency. Arch Physio Norm Pathol 5: 401-408.

16. Pollack SV, Carrytlers A, Grekin RC (2000) The history of electrosurgery. Dermatol Surg 26(10): 904-908.

\section{Your next submission with Juniper Publishers will reach you the below assets}

- Quality Editorial service

- Swift Peer Review

- Reprints availability

- E-prints Service

- Manuscript Podcast for convenient understanding

- Global attainment for your research

- Manuscript accessibility in different formats

( Pdf, E-pub, Full Text, Audio)

- Unceasing customer service

Track the below URL for one-step submission https://juniperpublishers.com/online-submission.php 